\title{
REVIEW
}

\section{Difficult-to-control asthma management through the use of a specific protocol}

\author{
Pedro Giavina-Bianchi, Marcelo Vivolo Aun, Carla Bisaccioni, Rosana Agondi, Jorge Kalil \\ Clinical Immunology and Allergy Department, Faculdade de Medicina, Universidade de São Paulo, São Paulo, SP, Brazil.
}

The present study is a critical review of difficult-to-control asthma, highlighting the characteristics and severity of the disease. It also presents a protocol for the management of patients with this asthma phenotype. The protocol, which was based on relevant studies in the literature, is described and analyzed.

KEYWORDS: Difficult-to-control; Asthma; difficult-to-treat; Asthma; severe asthma; Resistant asthma; Protocol; Management.

Giavina-Bianchi P, Aun MV, Bisaccioni C, Agondi R, Kalil J. Difficult-to-control asthma management through the use of a specific protocol. Clinics. 2010;65(9):905-918.

Received for publication on May 11, 2010; First review completed on May 18, 2010; Accepted for publication on June 2, 2010

E-mail: saudesos@terra.com.br

Tel.: 551130713189

\section{INTRODUCTION}

The worldwide prevalence of asthma is estimated at $10 \%$, which makes it a public health problem which has generated considerable interest among researchers. ${ }^{1-4}$

In Brazil, the local arm of the International Study of Asthma and Allergies in Childhood (ISAAC), which concentrates on children and adolescents, revealed a high prevalence of asthma symptoms (20-25\%) in most Brazilian cities. 5 Among prepubescent children, asthma is more common among boys. However, among adolescents and adults, women are more often affected and experience greater asthma severity than those in other groups.,

Another major facet indicating the influence of asthma on morbidity and mortality in Brazil is revealed by data regarding hospitalizations for asthma via the Brazilian Public Unified Health Care System, which is responsible for the treatment of $70-75 \%$ of the population. The number of hospitalizations annually for asthma has been in decline since 2000, when it peaked at 397,000 (Figure 1). ${ }^{9}$ Factors that might have contributed to this decrease in morbidity include the development and implementation of programs for the treatment of asthma in Brazil through which asthma medication is made available to patients at no charge. However, it is necessary to improve upon the activities already initiated and make them more homogeneous throughout the country.

The Hospital das Clínicas of the School of Medicine of São Paulo University (HC-FMUSP), located in the city of São Paulo, Brazil, is a tertiary care facility and, therefore, receives cases that are more complex and severe than those in other hospitals. It should be kept in mind that difficult-to-

Copyright (c) 2010 CLINICS - This is an Open Access article distributed under the terms of the Creative Commons Attribution Non-Commercial License (http:// creativecommons.org/licenses/by-nc/3.0/) which permits unrestricted noncommercial use, distribution, and reproduction in any medium, provided the original work is properly cited. control asthma, although accounting for no more than $5 \%$ of all asthma cases, is responsible for approximately $50 \%$ of the overall costs related to asthma treatment in Brazil. It is also associated with greater morbidity and mortality, a higher risk of emergency room treatment being needed, and of hospitalization, respectively, being 15 and 20 times greater for such patients than for those with less severe forms of asthma. ${ }^{10-13}$

Challenged by the high prevalence of asthma and by high asthma-related morbidity, which has a strong socioeconomic impact, various health care facilities, medical societies, and organizations have developed protocols and consensuses for a more effective approach to asthma and difficult-to-control asthma. ${ }^{1,12,14-17}$

In this context, a difficult asthma management protocol (DAMP) was developed at the Asthma Outpatient Clinic of

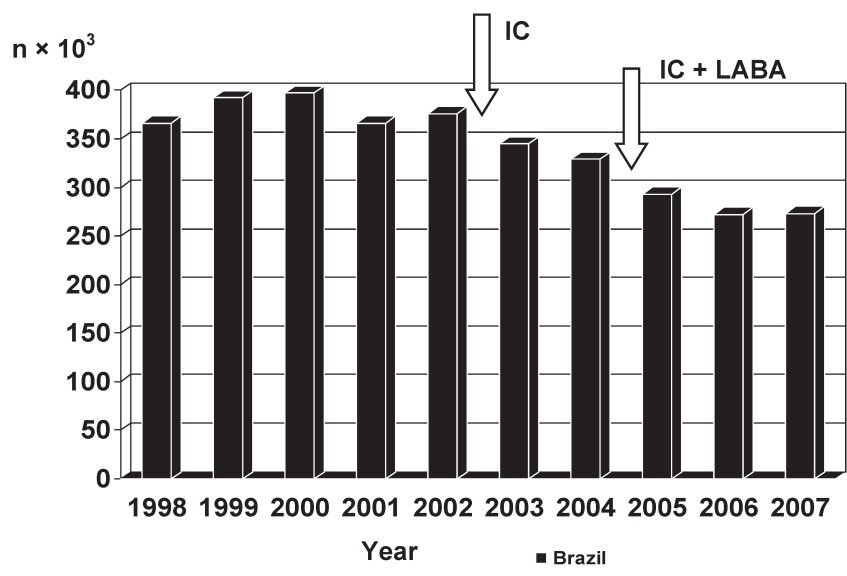

Figure 1 - Hospitalization due to asthma in Brazil as a whole and in São Paulo, Brazil in particular, according to data from the Information Technology Department of the Brazilian Unified Health Care System.

IC: inhaled corticosteroid; LABA: long-acting $\beta_{2}$ agonist 
the HC-FMUSP Department of Clinical Immunology and Allergy. The protocol requires the analysis of various situations which have been grouped into three blocks (Figure 2). Simultaneously, a line of research dedicated to this clinical entity was developed, allowing the execution of various studies that have been published in indexed journals and presented at national and international conferences. In addition to the DAMP, the development and implementation of electronic medical records has promoted the treatment of, education regarding, and research into asthma. ${ }^{18}$

Besides the protocol discussion, the authors reviewed the literature, mainly the Global Initiative for Asthma (GINA) guidelines, to classify the recommendations presented here on the basis of level of evidence (Figure 3).

\section{DISCUSSION}

\section{Difficult-to-control Asthma}

By consensus, the term "difficult-to-control asthma" is used in medical literature worldwide. However, various other terms, such as "difficult asthma," "difficult-to-treat asthma," "resistant asthma" and "refractory asthma," are also used. Most patients with difficult-to-control asthma have severe corticosteroid-dependent asthma or severe corticosteroid-insensitive asthma.

The 2006 Latin American Consensus on Difficult-toControl Asthma defined the disease as an asthma that is insufficiently controlled despite appropriate therapeutic strategies adjusted to the degree of clinical severity of the disease. ${ }^{19,20}$ Although this definition is subject to a certain degree of subjectivity, it represents a group of patients who have specific characteristics and, therefore, should be approached in a special manner. With the purpose of making the diagnosis of difficult-to-control asthma more objective, various consensuses have proposed primary and secondary criteria. The Latin American Consensus has defined difficult-to-control asthma as asthma that meets at least one of the primary criteria and one of the secondary

\section{DIFFICULT-TO-CONTROL ASTHMA}

\section{BLOCK I}

Confirm the diagnosis

Environmental control

Treatment adherence

Appropriate education of patient

Treatment optimization

\section{BLOCK III}

Multidisciplinary evaluation

Corticosteroid resistance

Neutrophilic asthma

Alternative therapies
(Manner of using the medication)

Figure 2 - Protocol for the treatment of patients with difficult-tocontrol asthma.

VCD: vocal cord dysfunction; ABPA: allergic bronchopulmonary aspergillosis; NSAIDs: nonsteroidal anti-inflammatory drugs; CSS: Churg-Strauss syndrome criteria or both primary criteria (Figure 4). ${ }^{19}$ In practice, it can be said that patients have difficult-to-control asthma if they present asthma that has been treated with systemic corticosteroids for more than six months or that remains uncontrolled despite the administration of high doses of an inhaled corticosteroids (IC) in combination with a longacting $\beta_{2}$ agonist (LABA).

After the 2006 revision of the Global Initiative for Asthma (GINA) guidelines, the criteria used to classify asthma patients as having controlled asthma became stricter: presenting with nearly asymptomatic disease (no nighttime symptoms and a maximum of two episodes of daytime symptoms);presenting with no exacerbations;using rescue medication twice a week at most;presenting with no limitations in physical activity;presenting with no adverse reactions to the drugs used;and presenting with normal pulmonary function test results.

As of yet, there is no consensus regarding the best manner to measure asthma control (Figure 5). Some of these measurements are routinely used during outpatient treatment, whereas others are used specifically in clinical research. These measurements do not always correlate with each other, underscoring the need to analyze the results of various methods of assessment in conjunction with each other. For instance, forced expiratory volume in one second $\left(\mathrm{FEV}_{1}\right)$, one of the indices that is most widely used to monitor patients, might not correlate with levels of exhaled nitric oxide or with scores on questionnaires designed to measure asthma control. ${ }^{21-23}$ The latter were created for the purpose of structuring and standardizing the evaluation of patients, thereby including clinical data and pulmonary function data, as well as data regarding inflammation (Figure 6). Some questionnaires have been validated and are easy to administer, as well as capable of being graded by scores that allow patient monitoring over a period of time.

Asthma is currently regarded as a syndrome, or at least as a disease that has various phenotypes. ${ }^{24-26}$ The two principal phenotypes, which have clear and distinct characteristics, are allergic and non-allergic asthma. In addition to the classification according to etiology, asthma can be classified according to severity and level of control.

In patients with allergic asthma, the onset of symptoms tends to be earlier, the disease progresses in a more benign manner, the rate of hypersensitivity to non-steroidal antiinflammatory drugs (NSAIDs) is lower, and the clinical history (personal and family) usually includes other atopic diseases (Figure 7). Exacerbations in these patients are characteristically related to exposure to aeroallergens. Patients with allergic asthma present with increased serum levels of total and specific immunoglobulin E (IgE). Specific IgE can be detected by in vivo tests (immediate skin test: skin prick test and intradermal test) and by in vitro tests (enzyme immunoassays). In rare cases, specific $\operatorname{IgE}$ is detected only at the site of the allergic process (local allergy). ${ }^{27,28}$

In both phenotypes, there is generally eosinophilic inflammation of the airways. ${ }^{29}$ However, neutrophilic infiltration is more common in non-allergic asthma. Studies have demonstrated that the number of neutrophils in induced sputum is significantly greater in patients with severe asthma than in those with mild asthma or in individuals without asthma. ${ }^{30}$ Neutrophilic inflammation has also been reported in acute exacerbations of the disease and in sudden-onset fatal asthma. ${ }^{31-33}$ 


\begin{tabular}{|c|c|c|}
\hline Evidence Category & Sources of Evidence & Definition \\
\hline $\mathrm{A}$ & $\begin{array}{l}\text { Randomized controlled trials } \\
\text { (RCTs). Rich body of data. }\end{array}$ & $\begin{array}{l}\text { Evidence is from endpoints of well designed RCTs } \\
\text { that provide a consistent pattern of findings in the } \\
\text { population for wich the recommendation is made. } \\
\text { Category A requires substantial numbers of studies } \\
\text { involving substantial numbers of participants. }\end{array}$ \\
\hline B & $\begin{array}{l}\text { Randomized controlled trials } \\
\text { (RCTs). Limited body of } \\
\text { data. }\end{array}$ & $\begin{array}{l}\text { Evidence is from endpoints of intervention studies } \\
\text { that include only a limited number of patients, } \\
\text { posthoc or subgroup analysis of RCTs, or meta- } \\
\text { analysis of RCTs. In general, Category B pertains } \\
\text { when few randomized trials exist, they are small in } \\
\text { size, they were undertaken in a population that } \\
\text { differs from the target population of the } \\
\text { recommendation, or the results are somewhat } \\
\text { inconsistent. }\end{array}$ \\
\hline $\mathrm{C}$ & $\begin{array}{l}\text { Nonrandomized trials. } \\
\text { Obsevational studies. }\end{array}$ & $\begin{array}{l}\text { Evidence is from outcomes of uncontrolled or } \\
\text { nonrandomized trials or from observational studies. }\end{array}$ \\
\hline D & Panel consensus judgement. & $\begin{array}{l}\text { This category is used only in cases where the } \\
\text { provision of some guidance was deemed valuable but } \\
\text { the clinical literature addressing the subject was } \\
\text { insufficient to justify placement in one of the other } \\
\text { categories. The Panel Consensus is based on clinical } \\
\text { experience or knowledge that does not meet the } \\
\text { above-listed criteria. }\end{array}$ \\
\hline
\end{tabular}

Figure 3 - Description of levels of evidence (Adapted from GINA).

Respiratory allergy is an example of a type I hypersensitivity reaction in which the allergen is presented to the $\mathrm{T}$ lymphocyte that will mediate a Th2 immune response, forming IgE antibodies. ${ }^{34-36}$ It is quite characteristic for a

\section{Primary criteria}

SCs used for more than 6 months in the last year

High-doses of ICs combined with LABA

\section{Secondary criteria}

$\mathrm{FEV}_{1}<80 \%$ or PEF variance $>20 \%$

Daily use of LABAs

SC courses: more than three times in the last year

Visits to the emergency room in the last year

Potentially fatal asthma attack

Worsening of PFT results after reduction in IC use

Figure 4 - Criteria for the diagnosis of difficult-to-control asthma. SC: systemic corticosteroid; IC: inhaled corticosteroid; LABA: long-acting $\beta_{2}$ agonist; $F E V_{1}$ : forced expiratory volume in one second; PEF: peak expiratory flow; PFT: pulmonary function test type I hypersensitivity reaction to occur in two phases: an immediate phase, occurring as a result of the degranulation of mast cells and basophils, and a late phase, occurring due to the recruitment (through chemotaxis) of other cells, such as eosinophils, which migrate to the site of inflammation. When the process becomes chronic, these phases overlap. ${ }^{37,38}$ In fact, the immune response is a network, within which various cells communicate through the secretion of cytokines and adhesion molecule expression. A recent study suggested that allergic asthma can be triggered by a Th2 response, even without the presence of $\operatorname{IgE} .^{39}$

In contrast to allergic asthma, the pathophysiology of which is well-characterized, the etiology of and mechanisms involved in non-allergic asthma remain unclear. Some of the possibilities include allergy triggered by unknown antigens (fungi), persistent infection (caused by Chlamydia trachomatis, Mycoplasma sp. or viruses), and autoimmunity.

A prospective study involving 300 consecutive patients referred to us with working diagnoses of asthma and rhinitis revealed that $68.4 \%$ of them presented sensitization to at least one aeroallergen, as demonstrated by skin prick 


\begin{tabular}{|l|}
\hline Clinical History and Clinical Examination \\
\hline Pulmonary Function Tests (FEV ${ }_{1}$ and PEF) \\
\hline Questionnaires to Measure Asthma Control (ACT, ACQ, ATAQ, ACSS) \\
\hline Nonspecific Bronchial Provocation \\
\hline Induced Sputum \\
\hline Exhaled Nitric Oxide \\
\hline Quality of Life Questionnaire (AQLQ) \\
\hline
\end{tabular}

Figure 5 - Assessment of asthma control.

$\mathrm{FEV}_{1}$ : forced expiratory volume in one second; PEF: peak expiratory flow; $\mathrm{ACT}$ : asthma control test; $\mathrm{ACQ}$ : asthma control questionnaire; ATAQ: asthma therapy assessment questionnaire; ACSS: asthma control scoring system; AQLQ: asthma quality of life questionnaire

tests. The allergens that presented the highest rates of sensitization were, in decreasing order, dust mite allergens, cockroach allergens, and cat allergens. ${ }^{40}$

Difficult-to-control asthma can also be considered a specific phenotype of asthma, and, as suggested by the 2006 Latin-American Consensus on Difficult-to-Control Asthma, difficult-to-control asthma can be subdivided into other phenotypes: labile asthma type I and II, corticosteroidresistant asthma, corticosteroid-dependent asthma, and near-fatal asthma. ${ }^{19,41}$

Various studies, such as the one by the European Network For Understanding Mechanisms Of Severe Asthma (ENFUMOSA study), which was conducted in 2003, have characterized difficult-to-control asthma. ${ }^{8}$ According to the study, this phenotype was more prevalent in non-allergic asthma and among females. In adults, the female/male ratio was 1.6:1 for asthma in general, compared with 4.4:1 for difficult-to-control asthma. Inflammation with a predominance of neutrophils was also more common in this phenotype; a prevalence of $36 \%$ was observed, in comparison with a prevalence of $28 \%$ in all asthma cases.

Although there is a consensus that most types of severe asthma are non-allergic, the Epidemiology and Natural History of Asthma: Outcomes and Treatment Regimens study (TENOR study) showed that, in children, IgE levels are markers of severity. ${ }^{42}$

We investigated hospital morbidity due to asthma, analyzing the factors associated with the need for hospitalization due to asthma. ${ }^{43}$ Most of the patients in our study were female and presented with moderate or severe asthma. Rhinosinusitis predominated among the associated diseases and respiratory infections were the principal cause of hospitalization. Most patients presenting with a history of smoking had been able to quit the habit. The three principal factors associated with hospitalization were as follows: poor treatment adherence, underuse of corticosteroids, and prior hospitalization.

Various studies have evaluated the relationship between the severity of asthma and genetic polymorphism: ${ }^{44-51}$

\begin{tabular}{|l|l|l|l|l|}
\hline PARAMETER & ACQ & ATAQ & ACT & ACSS \\
\hline Nighttime Symptoms & $\mathrm{X}$ & & $\mathrm{X}$ & $\mathrm{X}$ \\
\hline Daytime Symptoms & $\mathrm{X}$ & $\mathrm{X}$ & $\mathrm{X}$ & $\mathrm{X}$ \\
\hline Limitation of Activities & $\mathrm{X}$ & $\mathrm{X}$ & $\mathrm{X}$ & $\mathrm{X}$ \\
\hline Relief Medication & $\mathrm{X}$ & $\mathrm{X}$ & $\mathrm{X}$ & $\mathrm{X}$ \\
\hline Pulmonary Function Tests & $\mathrm{FEV}$ & & & FEV/PEF \\
\hline Self-Reported & & $\mathrm{X}$ & $\mathrm{X}$ & \\
\hline Severity of Symptoms & $\mathrm{X}$ & & & \\
\hline Inflammation Markers & & & & \%ES \\
\hline Assessment Interval & week & month/year & month & ND \\
\hline Score & $0-6$ & & $5-25$ & \\
\hline
\end{tabular}

Figure 6 - Questionnaires to measure asthma control.

ACT: asthma control test; ACQ: asthma control questionnaire; ATAQ: asthma therapy assessment questionnaire; ACSS: asthma control scoring system; FEV 1 : forced expiratory volume in one second; PEF: peak expiratory flow; and \%ES: percentage of eosinophils in sputum; ND: not determined 


\begin{tabular}{|l|c|c|}
\hline CHARACTERISTIC & ALLERGIC ASTHMA & NONALLERGIC ASTHMA \\
\hline Synonym & Extrinsic asthma & Intrinsic asthma \\
\hline Onset & Early & Late \\
\hline Worsening with allergens & + & - \\
\hline Personal history of atopy & + & More frequent \\
\hline Family history of atopy & + & Unknown \\
\hline Intolerance to NSAIDs & Less frequent & Normal \\
\hline Pathophysiology & Type I hypersensitivity & - \\
\hline Total IgE & Elevated & + or - \\
\hline Specific IgE & + & Less favorable \\
\hline Eosinophils (blood/sputum) & More favorable & \\
\hline Evolution & & \\
\hline
\end{tabular}

Figure 7 - Differences between allergic asthma and non-allergic asthma. NSAID: nonsteroidal anti-inflammatory drug; IgE: immunoglobulin $\mathrm{E}$

- IL-4 and its receptor.

- Genes related to fibrosis (transforming growth factorbeta 1 and monocyte chemoattractant protein-1).

- Genes related to pharmacogenetics (aspirin-intolerant asthma;responses to corticosteroids, $\beta-2$ adrenergic agonists and leukotriene antagonists).

Exposure to tobacco smoke and continuous exposure to aeroallergens, principally dust mite aeroallergens, fungi aeroallergens, cockroach aeroallergens, and rat aeroallergens, are also associated with severe asthma (Evidence B). ${ }^{52-}$

55 The same occurs with infections caused by the respiratory syncytial virus, Chlamydia trachomatis or Mycoplasma sp. ${ }^{56}$

\section{The Protocol}

The DAMP, developed in the HC-FMUSP Department of Clinical Immunology and Allergy, is based on three blocks (sets) of measures (Figure 2).

Block I. In the first block, the measures focus on analyzing situations that are more commonly associated with asthma that remain uncontrolled despite the use of theoretically appropriate treatments. In this block, it is suggested that the diagnosis of the disease be confirmed and that environmental controls, treatment adherence, and medication use be evaluated (Evidence B) and that treatment be optimized (Evidence A).

Studies have reported that, in most cases, by improving the evaluation and treatment of these patients, asthma can be controlled without the continuous use of systemic corticosteroids or immunosuppressants (Evidence A). ${ }^{19,57}$ In a study of Leal OM, the potentially aggravating factors of asthma were, in decreasing order of frequency, as follows: unsatisfactory knowledge of the disease, incorrect techniques in terms of using medications, gastroesophageal reflux, inappropriate environmental controls, poor treatment adherence, rhinosinusitis and polyposis, emotional factors, allergic bronchopulmonary aspergillosis (ABPA), vocal cord dysfunction (VCD), failure to use the recommended IC, and intolerance to NSAIDs. ${ }^{58}$

The Spanish Consensus on Asthma Management has divided difficult-to-control asthma into two subgroups: true difficult-to-control asthma and false difficult-to-control asthma. False difficult-to-control asthma, perhaps the more common of the two, is that syndrome in which poor control is associated with factors that are not intrinsic to the disease itself, such as incorrect diagnoses of asthma and poor treatment adherence. This discussion is a more conceptual one since all patients with clinical profiles consistent with difficult-to-control asthma should initially be regarded as having the disease so that the factors that influence disease control can be properly identified, approached, and modified. $^{15}$

According to the DAMP, the diagnosis of asthma should first be confirmed because asthma may be mistaken for or, more commonly, accompanied by chronic obstructive pulmonary disease or congestive heart failure. In some patients who smoke, it is extremely difficult to distinguish between pulmonary involvement due to asthma and that due to chronic obstructive pulmonary disease.

Whether environmental control is being properly performed and whether all allergens and irritants involved have been identified and avoided should also be investigated. The treatment of respiratory allergies has traditionally been divided into three parts: environmental control, pharmacological treatment, and immunotherapy. The division is purely instructive since these three treatment modalities complement one another and should be employed in conjunction with each other.

Although there is a rationale, as well as evidence for the need to adopt preventive measures to reduce the number of aeroallergens in the environment (Evidence B), some studies have been unable to confirm the impact of such measures on disease control. ${ }^{59,60}$ The difficulty in confirming the effectiveness of environmental control is due, at least in part, to 
poor treatment adherence and the complexity of asthma, a disease that results from the interaction between various environmental and genetic factors. ${ }^{61}$ Among the irritants that are associated with a less favorable evolution of asthma, smoking and pollution are noteworthy (Evidence B). ${ }^{62-64}$

In patients with difficult-to-control asthma, the possibility of occupational asthma should always be considered and the knowledge that avoidance of identified allergens improves disease control (Evidence A). ${ }^{65}$ Specific bronchial provocation using allergens to confirm the etiology of asthma is rarely performed in routine clinical practice. However, it is an important tool for the diagnosis of inconclusive clinical cases and for the conducting of research. ${ }^{66,67}$ Specific bronchial provocation is safe, provided that it is performed in a standardized manner which follows protocols. ${ }^{68-73}$

It is likely that the most common causes of uncontrolled asthma are poor treatment adherence and insufficient knowledge on the part of the patient, which results, for example, in the incorrect use of medication. It is estimated that asthma treatment adherence ranges from 30 to $50 \%{ }^{74}$ After a trusting relationship has been established between the health professional and the patient, the importance of treatment adherence should be discussed and measures to ensure that the patient remembers to take the medication should be proposed (Evidence B). Open dialogue, through clear and direct questions, is the most appropriate method for determining whether the proposed treatment regimen is being followed. ${ }^{75}$

A series of studies conducted on various continents revealed that most asthma patients have uncontrolled asthma, are not aware of that fact, have not been properly educated, and are not being correctly monitored (Figure 8). Underuse of ICs, which is observed even among patients with extremely severe asthma, is among the principal causes of uncontrolled asthma. ${ }^{76-79}$ One study demonstrated eosinophilic inflammatory infiltration throughout the airways of deceased individuals who had presented with fatal asthma. Many of these individuals were not treating their asthma regularly and were not using ICs. ${ }^{80}$

Although physicians should develop strategies of education and guidance (which include giving patients written treatment plans - Evidence A), some studies have demonstrated that health professionals are not always trained in

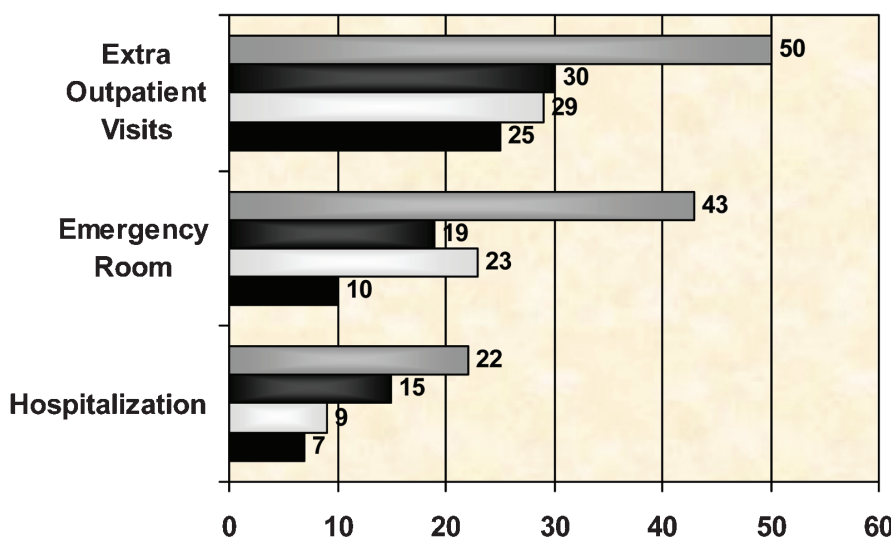

Europe $\square$ USA $\square$ Asia-Pacific $\square$ Latin America

Figure 8 - Rate of severe exacerbations of asthma in the last year. how to do that. ${ }^{81,82}$ Patients should know that the respiratory symptoms of asthma result from an inflammatory process in the airways, that there are drugs to treat exacerbations and others used as maintenance drugs and that, although asthma is chronic, the disease can be controlled through treatment, improving quality of life and reducing morbidity. ${ }^{83}$ There are various devices for administering the drugs through inhalation, and the techniques for using such devices should be taught and checked at every medical visit as part of the examination. The use of a peak expiratory flow meter should also be demonstrated because this will allow home monitoring of pulmonary function (Evidence B).

Regarding treatment optimization, it is assumed that the amount of medication prescribed should be the lowest possible to maintain and control the asthma.

The 2006 update of the GINA guidelines proposed a new asthma classification based on disease control evaluation: controlled asthma, partially controlled asthma, and uncontrolled asthma. As previously described, the criteria for this new classification are also rigorous.

The Gaining Optimal Asthma controL (GOAL) study, conducted in 2004, had a great influence on the changes in the GINA guidelines. ${ }^{84}$ It showed that most patients with asthma do not fully respond to the treatments they were given. However, treatment response can be achieved through more rigorous approaches. The GOAL study also suggested that asthma control can be achieved more rapidly and in a greater percentage of patients through the use of ICs in combination with LABAs.

The Salmeterol Multicenter Asthma Research Trial (SMART) study, conducted in 2006, put in check the indiscriminate use of LABAs in patients with asthma. ${ }^{85}$ The SMART was a multicenter, randomized, double-blind, placebo-controlled study that evaluated 26,355 patients. There was a small increase in mortality related to the use of LABAs, principally in African-American patients.

The GINA currently recommends a combination therapy (ICs and LABAs) for patients with moderate or severe asthma that has not been controlled by IC use alone. It is known that, when used continuously, LABAs should always be prescribed in combination with ICs. ${ }^{86}$ However, the question regarding the dose of IC with which LABAs should first be combined remains unanswered. Is it better 


\begin{tabular}{|l|}
\hline To establish a consensus and develop guidelines for the treatment of allergic rhinitis \\
\hline To disseminate the consensus to general practitioners and specialists \\
\hline To highlight the impact of allergic rhinitis on asthma \\
\hline To establish a forum for a multidisciplinary discussion regarding respiratory allergies
\end{tabular}

Figure 9 - Objectives of the Allergic Rhinitis and its Impact on Asthma initiative.

for patients to receive high doses of an IC or moderate doses of an IC in combination with a LABA?

In recent decades, the use of ICs has become the standard treatment for patients with persistent asthma. The administration through inhalation has improved disease control, reducing mortality and, simultaneously, the side effects triggered by the use of systemic steroids (Evidence A). ${ }^{87}$

However, certain local effects, such as oropharyngeal candidiasis and dysphonia, can occur and can lead patients to discontinue treatment. ${ }^{88}$ With the increase in the use and doses of ICs, studies have also reported esophageal candidiasis as being a complication of asthma treatment. ${ }^{89-91}$ Esophageal candidiasis is underdiagnosed and often oligosymptomatic. The diagnosis is made only when there is a high degree of suspicion, principally in patients using high doses of ICs.

It has been demonstrated that only by changing ICs and inhalers can this complication be avoided and treated. ${ }^{92}$ Another interesting observation is that, just as oral asepsis after IC use prevents oral moniliasis, the ingestion of fluids and solids may prevent and treat esophageal infection. ${ }^{93}$ This effectively constitutes esophageal lavage and removes the medication deposited in the mucosa.

The treatment of asthma should always be adjusted so that the morbidity and mortality from the disease are as low as possible, providing patients with a better quality of life. Complete control should always be the goal. However, when this goal cannot be achieved, the objective of the treatment should be to attain the best response and the fewest adverse reactions. Once asthma is properly controlled by a treatment regimen, the medication dose should be progressively reduced to the minimum required to maintain disease control.

Block II. In the second block of the DAMP, co-morbidities and associated diseases should be investigated and identified because the treatment of these diseases aids in controlling asthma.

We have recently analyzed the data obtained from the electronic medical records of 245 patients treated for severe asthma. ${ }^{94}$ Rhinitis, gastroesophageal reflux disease (GERD), and bronchiectasis were the most common co-morbidities observed, showing a high prevalence. Therefore, in patients with severe asthma, associated diseases should be investigated as the cause of respiratory symptoms and uncontrolled asthma. Some of the principal entities that aggravate the progression of asthma are described and discussed below.

Rhinosinusitis. Rhinitis is an inflammatory disease of the nasal mucosa that is clinically characterized by four principal symptoms: rhinorrhea, sequential sneezing, pruritus, and nasal congestion. ${ }^{95,96}$ In the case of allergic rhinitis, the inflammatory process is induced by an IgEmediated immune response.
Rhinitis-related morbidity is high and represents a heavy socioeconomic burden due to direct and indirect costs. ${ }^{95-101}$ The estimated prevalence of allergic rhinitis in the general population is $30 \%$, and allergic rhinitis is the most common chronic disease in children, which makes it a serious public health problem. ${ }^{95,96,102,103}$

The ARIA consensus was published in $2001 .{ }^{96}$ In addition to some new conceptual modifications regarding rhinitis, such as a change in the classification of the disease, the ARIA highlighted the importance of being aware of the influence that the upper airways exert on the lower airways and vice-versa (Figure 9). ${ }^{96,104}$

Allergic rhinitis and allergic asthma are currently recognized as manifestations of a single entity, "chronic allergic respiratory disease," also known as "united airway disease." There is epidemiological, pathophysiological, and clinical evidence to support an integrated view of these diseases, allowing a better understanding of their interactions (Figure 10)..$^{96,97,105-108}$ The great majority of patients with asthma have rhinitis, the latter being a risk factor for the development of the former.

Some studies have demonstrated that the presence of severe rhinitis in patients with asthma is associated with less favorable evolution. It has also been shown that the treatment of nasal symptoms can be beneficial to the lower airways (Evidence A), reducing the number of emergency room visits and hospitalizations, as well as the severity of bronchial hyperreactivity. ${ }^{106,109-112}$

These studies and others with similar results do not suggest that patients with rhinitis and asthma should be treated with nasal medications alone; what they do recommend is that the teachings of the ARIA initiative should not be forgotten.

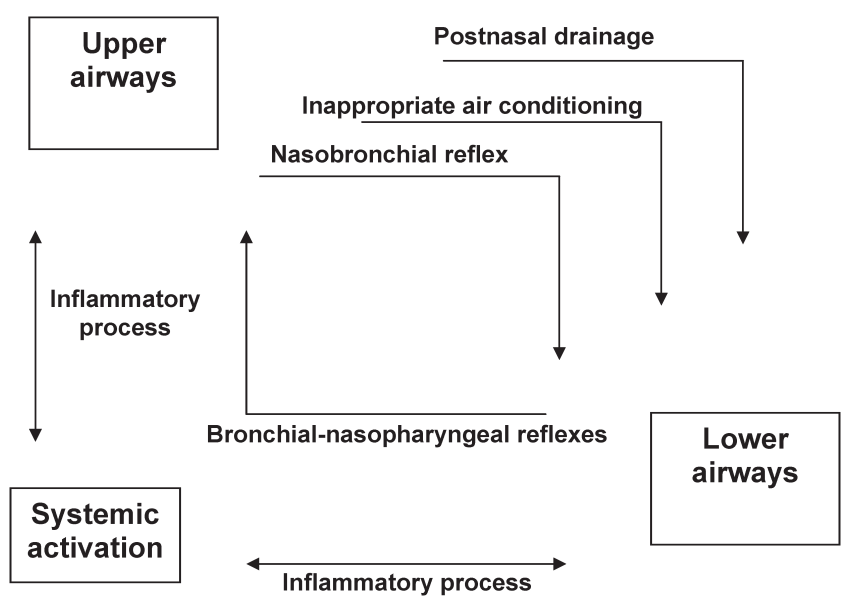

Figure 10 - Pathophysiological evidence for the interaction between allergic rhinitis and allergic asthma. 
Gastroesophageal Reflux Disease (GERD). Patients with GERD can present with respiratory manifestations. The prevalence of GERD is higher in patients with asthma than in the general population, and GERD is associated with difficult-to-control asthma. However, there is no definitive scientific evidence that the treatment of one of the two diseases translates to a more favorable progression of the other (Evidence C).

Asthma and GERD frequently coexist. ${ }^{113}$ Concomitance between symptoms of dyspnea and reflux is quite common, and large-scale studies have shown that the degree of reflux can be as much as $60 \%$ greater in individuals with asthma than in those without. ${ }^{114}$ In a study conducted in the United Kingdom, the prevalence of GERD symptoms among patients with difficult-to-control asthma was found to be $75 \%{ }^{115}$

It has been shown that GERD exacerbates asthma through mechanisms involving vagus nerve stimulation (esophagobronchial reflex) or microaspiration of gastric contents into the airways.

Adverse Drug Reactions. Aspirin-induced asthma is a clinical entity characterized by asthma and intolerance to aspirin or NSAIDs. ${ }^{116}$ Aspirin-induced asthma and nasal polyposis (Samter triad) are associated with an increase in asthma severity. ${ }^{117,118}$

Although hypersensitivity to NSAIDs and aspirin affects only $0.6-2.5 \%$ of the general population of adults, it occurs in $5-20 \%$ of adults with asthma. ${ }^{119}$ It has previously been demonstrated that many patients are not able to perceive this exacerbation. In a study conducted in Europe and involving 500 patients diagnosed with aspirin-intolerant asthma, $90(18 \%)$ were unable to perceive any worsening of the symptoms prior to the provocation test. ${ }^{120}$

Vocal Cord Dysfunction (VCD). The features of VCD include episodes of involuntary paradoxical movements caused by vocal cord adduction during respiration and resulting in airway obstruction. The clinical profile is characterized by stridor, dyspnea, and wheezing, principally in the cervical region. Although VCD generally is seen in patients with asthma, it can also occur in an isolated form in individuals without respiratory disease.

The prevalence of VCD, which is higher in patients with difficult-to-control asthma, has yet to be well established. ${ }^{121}$ In Brazil, the prevalence of VCD in patients with severe asthma and difficult-to-control asthma were found to be $17.5 \%$ and $19.5 \%$, respectively. ${ }^{122}$ However, VCD is commonly underdiagnosed, which is responsible for the low reported prevalence of this disease at various health care facilities.

The pathophysiology of VCD is unknown, and no organic cause has yet been found. The most accepted hypothesis is that its etiology is psychogenetic and that attacks of VCD are commonly triggered by psychological factors. ${ }^{123-126}$

Two factors make VCD more intriguing and more difficult to diagnose than other similar diseases. First, there is a confounding overlap between asthma and VCD attacks when they coexist. ${ }^{121,124}$ Second, VCD appears as attacks, and certain patients, especially those with VCD in isolation, can be asymptomatic between attacks. Since there are no diagnostic criteria for VCD, clinical suspicion is based on discrepancies between the clinical profile, the complementary test results, and the therapeutic response.

A definitive diagnosis of VCD can be obtained by means of laryngoscopy. When performed during an attack, it shows a typical pattern, which consists of the adduction of the anterior two thirds of the vocal cords during inspiration, forming a posterior cleft with a "diamond shape."121,124

Many patients with VCD are misdiagnosed as having severe asthma or difficult-to-control asthma and, therefore, receive inadequate or inappropriate treatment since VCD treatment is based on psychotherapy and speech therapy (Evidence C). It should be noted that these patients receive the same treatment as do those with difficult-to-control asthma, including the continuous use of systemic corticosteroids. In addition to producing a limited clinical response, this treatment regimen has undesirable side effects (Evidence B). However, since most patients with VCD also suffer from asthma, the latter should not be ignored.

Recently, a specific questionnaire designed to raise awareness of the possibility of VCD was developed in order to identify patients who are more likely to be diagnosed with the disease (Figure 11). ${ }^{122}$ In essence, the questionnaire attempts to identify whether there are discrepancies or inconsistencies between the clinical profile, the complementary tests, and the treatment of the patient.

Allergic Bronchopulmonary Aspergillosis (ABPA). The complex disease ABPA is triggered by a hypersensitivity reaction to allergens of the fungus Aspergillus fumigatus. The prevalence of ABPA among asthma patients sensitized to $A$. fumigatus in Brazil has been reported to be $20 \%{ }^{127}$

The course of ABPA includes periods of exacerbation and remission. The disease can progress to a phase in which the patient presents with central bronchiectasis and pulmonary fibrosis, resulting in chronic respiratory failure. ${ }^{128}$

Since ABPA is accompanied by cystic fibrosis or asthma (especially difficult-to-control asthma), it is another disease in which the diagnosis is complicated. The challenge is to diagnose ABPA in its initial stages, when only the serological markers are present and the processes of cicatrization/fibrosis are not yet evident (ABPA with central bronchiectasis). Unfortunately, ABPA is often diagnosed only after years of monitoring, making it difficult to prevent irreversible lung damage. ${ }^{128-131}$

Some ABPA markers are difficult to detect (especially at the early stages of the disease) and, in general, the markers do not present simultaneously during a single evaluation. At least three factors make it difficult to diagnose the disease:

1) ABPA manifests as attacks.

2) The treatment of ABPA, which consists principally of using systemic corticosteroids, hinders with the diagnostic investigation.

3) The current methods for detecting specific antibodies (IgE and $\operatorname{IgG}$ ) are not accurate or easily reproduced.

Some studies, especially those involving patients with cystic fibrosis, have reported that, based on the humoral response to recombinant allergens, it is possible to distinguish between ABPA patients and asthma patients sensitized to A. fumigatus, but without ABPA. ${ }^{132,133}$ Other studies, however, have reported that determination of the serum levels of $\operatorname{IgE}$ against recombinant allergens of $A$. fumigatus does not aid in diagnosing ABPA or in confirming sensitization to the fungus. ${ }^{134,135}$

It has been reported that there is a discrepancy between the intradermal test results and the serology results in patients suspected of having ABPA. Intradermal tests seem 
Q1- Is there a history of frequent attacks at home, without a consistent clinical profile during medical visits?

Q2- Does the patient use continuous systemic corticosteroid or inhaled corticosteroid (or a combination of the two) at high doses without therapeutic response?

Q3- Does pulmonary auscultation reveal wheezing, predominantly in the cervical region?

Q4- Is pulmonary function testing $\left(\mathrm{FEV}_{1}\right)$ or peak expiratory flow inconsistent with the clinical profile?

Q5- Does pulmonary function testing reveal flattening of the inspiratory loop of the flow-volume curve, which is suggestive of extrathoracic obstruction?

Q6- Is oxygen saturation inconsistent with the intensity of the asthma attack?

Figure 11 - Specific questionnaire for the clinical suspicion of vocal cord dysfunction. $\mathrm{Q}$ : question; $\mathrm{FEV}_{1}$ : forced expiratory volume in one second; and PEF: peak expiratory flow

to be more sensitive, with late reactions having been reported. ${ }^{136}$

In this context, the diagnosis of ABPA remains complex and challenging.

Immunodeficiencies. Immunodeficiencies with recurrent respiratory infections are included in the differential diagnosis of asthma. However, when the two diseases are present in the same patient, the infections make asthma control difficult and they may trigger asthma exacerbations.

Secondary immunodeficiencies are more common than are primary immunodeficiencies and, in patients with asthma, the most prevalent type of immunodeficiency is that which results from corticosteroid therapy. ${ }^{137}$

Among the primary immunodeficiencies, the most prevalent are selective IgA immunodeficiency and common variable immunodeficiency (CVID), both of which are responsible for pulmonary infections and respiratory manifestations. ${ }^{138,139}$ The prevalence of respiratory impairment is high, and $25 \%$ to $50 \%$ of the patients present with bronchiectasis, obstructive pulmonary diseases, or restrictive pulmonary diseases. ${ }^{140,141}$ Recurrent infections are the principal cause of pulmonary involvement. However, a chronic inflammatory process, the etiopathogenesis of which remains unclear, is also observed in the lungs of these individuals. ${ }^{142,143}$ These data warrant intensive monitoring of the respiratory system of CVID patients and justify their treatment with gamma-globulin therapy, which has changed the prognosis of the disease (Evidence A). ${ }^{142,143}$

Many patients with CVID remain symptomatic, with respiratory complaints. These symptoms can mimic and be mistaken for those of asthma, and it is extremely difficult to confirm the diagnosis of asthma, as well as to determine the allergic etiology of asthma in patients with CVID.

We showed that in CVID patients, in addition to pulmonary function testing, bronchial provocations can aid in the diagnosis of asthma and can help to confirm the allergic etiology of the disease since the vast majority of patients present specific serum IgE that cannot be detected by skin tests or by in vitro tests. ${ }^{39}$
Although patients with CVID synthesize low quantities of antibodies, perhaps the production of $\operatorname{IgE}$ in the airways can be enough to trigger allergic asthma. Another hypothesis has to be considered: the existence of a Th2 immune response with participation and activation of $\mathrm{T}$ lymphocytes, mast cells and eosinophils, without the presence of the IgE antibody.

Churg-Strauss Syndrome. Churg-Strauss syndrome (CSS) is a necrotizing systemic vasculitis of medium and small blood vessels characterized by asthma, eosinophilia, and eosinophilic or granulomatous tissue inflammation. It is currently recognized as one of the antineutrophil cytoplasmic antibody (ANCA)-associated vasculitides which is present in half of all CSS patients. ${ }^{144-146}$

Asthma and upper respiratory symptoms are present in nearly all CSS patients, besides the presence of other manifestations of systemic vasculitis. The syndrome manifests in three consecutive phases: a prodromal phase consisting of respiratory manifestations (rhinosinusitis and asthma), a second phase consisting of peripheral blood eosinophilia and eosinophilic tissue infiltrates, and a third phase consisting of systemic vasculitic manifestations. ${ }^{147-150}$

Corticosteroids are the cornerstone of CSS therapy and provide control of disease activity in the great majority of cases (Evidence A). However, 25-50\% of CSS patients relapse within two years of achieving remission and a substantial proportion of patients present adverse drug reactions with significant morbidity. ${ }^{147-149,152}$ Asthma is not considered in the definition of CSS remission, and most patients continue to present with asthma and upper respiratory symptoms, requiring ongoing treatment.

We reported the first case of a patient with CSS who received anti-IgE antibodies for the treatment of difficult-tocontrol asthma. ${ }^{153,154}$ In parallel with the description of our clinical case, there were case reports of patients who developed CSS during anti-IgE antibody use. ${ }^{155-157}$ These studies have sparked a discussion as to whether omalizumab can trigger CSS, a discussion that is similar to that regarding anti-leukotrienes. After the analysis of the cases, it 
is argued that the patients probably had CSS before the use of the anti-IgE antibody and that the disease was masked by the use of systemic corticosteroids. The use of the anti-IgE antibody allowed the discontinuation of the systemic corticosteroids, increasing the activity of CSS and allowing the diagnosis to be made. ${ }^{158-162}$

Discontinuation of the use of systemic corticosteroids in patients with asthma, especially in those with severe asthma who are suspected of having CSS, should be undertaken with care.

Block III. After the situations and co-morbidities described in Blocks I and II have been identified and controlled, additional measures might be necessary.

Due to the specialization and deepening of knowledge in the health area, diseases that are more severe and complex might be approached more effectively if multiprofessional and multidisciplinary teams were to be involved. Some studies have demonstrated the benefits of physical therapy and physical exercise to treat asthma (Evidence C). ${ }^{163-165}$ Psychological evaluation can also be beneficial, principally in prolonged and severe cases (Evidence C). It has been shown that the prevalence of symptoms of anxiety and depression is higher in patients with asthma than in patients with chronic obstructive pulmonary disease. ${ }^{166}$

In a minority of patients, prolonged, continuous use of systemic corticosteroids, often at high doses, is required. When the use of systemic corticosteroids is discontinued, asthma control worsens. In patients with this type of asthma, which is designated corticosteroid-dependent asthma, the adverse effects of the treatment become a serious problem (Evidence A).

A small portion of patients do not respond adequately to glucocorticoids, regardless of the dosage. These patients are designated corticosteroid-insensitive or corticosteroid-resistant, and they also present with severe side effects. ${ }^{167}$ The lack of response to the medication might be only partial and might occasionally be reversed by treating the inflammatory process. Clinically, patients with corticosteroid-insensitive asthma are those who present with an $\mathrm{FEV}_{1}<70 \%$ of the predicted value and who do not show a $15 \%$ and a $200 \mathrm{ml}$ improvement in $\mathrm{FEV}_{1}$ after treatment with prednisolone $40 \mathrm{mg}$ (or equivalent), for 14 days. If there is no treatment response, the dose can be doubled for an additional 14 days. $^{168}$

In cases in which insensitivity to corticosteroids is due to a reduction in the affinity between the drug and its receptor at least two mechanisms have been described. ${ }^{169,170}$ There can be genetic (inherited) modifications in the receptors or, more commonly, the inflammatory process induces a reduction in affinity.

Neutrophilic asthma is another phenotype of the disease that might not respond adequately to glucocorticoids. ${ }^{171-173}$ These drugs antagonistically induce and inhibit the apoptosis of eosinophils and neutrophils, respectively. There is controversy in the literature as to whether the neutrophilic infiltrate is the cause of airway inflammation or a consequence of the chronic use of corticosteroids. There is evidence that, in the bronchial mucosa of patients with difficult-to-control asthma, eosinophils predominate in some cases and neutrophils predominate in others (Evidence B). There are also two subgroups of fatal asthma: sudden-onset fatal asthma, which is accompanied by neutrophilic inflammation, and slow-onset fatal asthma, which is accompanied by eosinophilic infiltrate. ${ }^{32}$
Various drugs that somehow modulate inflammation have been used as alternative treatments in corticosteroidinsensitive and corticosteroid-dependent patients (Evidence C). Such drugs include colchicines, chloroquine, dapsone, macrolides, immunoglobulins, gold salts, azathioprine, cyclosporine, and methotrexate. ${ }^{19}$ Although some of these agents might be useful in treating certain patients, they do not have consistent effects and some of them have been associated with severe adverse reactions. In the absence of studies determining the subgroups of patients that would benefit the most from using these drugs, they should be prescribed on a caseby-case basis.

Omalizumab is a humanized anti-IgE monoclonal antibody that has recently been made available in Brazil for the treatment of difficult-to-control allergic asthma. The clinical effectiveness of omalizumab has been proven in various studies, principally with regard to the following parameters: exacerbations, quality of life, use of rescue medication, and reduction in the use of ICs (Evidence B).[174-176] The principal challenges facing the use of omalizumab are the correct characterization of the profile of patients who would benefit the most from anti-IgE antibody use and the limited access to the medication, which is principally due to its high cost.

\section{CONCLUSIONS}

Asthma is a chronic disease of high prevalence and a public health problem. It affects individuals of all ages and, if left uncontrolled, it causes limitations of activities of daily living and can lead to death.

The treatment of asthma, principally that of the allergic phenotype, has greatly evolved, and the vast majority of patients can present with controlled asthma, no symptoms, and normal pulmonary function. However, a small but significant portion of individuals with asthma present with difficult-to-control asthma, which is associated with high morbidity and cost.

The development of protocols for the treatment of difficult-to-control asthma, such as that which is presented in the present study, have allowed patients with this disease to be managed more effectively, possibly reducing morbidity and mortality and improving their quality of life. The objective of the protocols is to guide physicians; they do not exclude the idea of personalized medicine.

\section{REFERENCES}

1. GINA. The Global Initiative for Asthma. Disponível em: www.ginasthma. com

2. Moorman JE, Rudd RA, Johnson CA, King M, Minor P, Bailey C, et al. National surveillance for asthma - United States, 1980-2004. MMWR Surveill Summ 2007;56:1-54

3. Strachan DP. Hay fever, hygiene, and household size. BMJ 1989;299:1259-60, doi: 10.1136/bmj.299.6710.1259.

4. Anderson HR, Gupta R, Strachan DP, Limb ES. 50 years of asthma: UK trends from 1955 to 2004. Thorax 2007;62:85-90, doi: 10.1136/thx.2006. 066407.

5. Solé D, Yamada E, Vana AT, Costa-Carvalho BT, Naspitz CK. Prevalence of asthma and related symptoms in school-age children in São Paulo, Brazil - International Study of Asthma and Allergies in Children (ISAAC). J Asthma. 1999;36:205-12, doi: 10.3109/02770909909056318.

6. Solé D, Yamada E, Vana AT, Werneck G, Solano de Freitas L, et al. International study of asthma and allergies in childhood (ISAAC): prevalence of asthma and asthma-related symptoms among Brazilian schoolchildren. J Investig Allergol Clin Immunol. 2001;11:123-8.

7. Almqvist C, Worm M, Leynaert B, working group of GA2LEN WP 2.5 Gender. Impact of gender on asthma in childhood and adolescence: a GA2LEN review. Allergy. 2008;63:47-57. 
8. ENFUMOSA. The ENFUMOSA cross-sectional European multicentre study of the clinical phenotype of chronic severe asthma. European Network for Understanding Mechanisms of Severe Asthma. Eur Respir J. 2003;22:470-7, doi: 10.1183/09031936.03.00261903.

9. DATASUS. Disponível em: www.datasus.com

10. Barnes PJ, Woolcock AJ. Difficult asthma. Eur Respir J. 1998;12:1209-18, doi: 10.1183/09031936.98.12051209.

11. Serra-Batlles J, Plaza V, Morejón E, Comella A, Brugues J. Costs of asthma according to the degree of severity. Eur Respir J. 1998;12:1322-6, doi: $10.1183 / 09031936.98 .12061322$.

12. American Thoracic Society. Proceedings of the ATS Workshop on Refractory Asthma. Current understanding, recommendations, and unanswered questions. Am J Respir Crit Care Med. 2000;162:2341-51.

13. Antonicelli L, Bucca C, Neri M, De Benedetto F, Sabbatani P, Bonifazi F, et al. Asthma severity and medical resource utilization. Eur Respir J. 2004;23:723-9, doi: 10.1183/09031936.04.00004904.

14. Chung KF, Godard P, Adelroth E, Ayres J, Barnes N, Barnes P, et al. Difficult/therapy-resistant asthma: the need for an integrated approach to define clinical phenotypes, evaluate risk factors, understand pathophysiology and find novel therapies. ERS Task Force on Difficult/Therapy-Resistant Asthma. European Respiratory Society. Eur Respir J. 1999;13:1198-208.

15. Plaza Moral V, Álvarez Gutiérrez FJ, Casan Clará P, Cobos Barroso N, López Viña A, Llauger Rosselló MA, et al. GEMA. Guía Española para el Manejo del Asma en calidad de Comité Ejecutivo de la GEMA y en representación del grupo de redactores. Arch Bronconeumol. 2003;39:S1-42, doi: 10.1157/13042409.

16. López-Viña A, Agüero-Balbín R, Aller-Álvarez JL, Bazús-González T, Garcia-Cosio FB, Diego-Damiá A, et al. Área de Asma-SEPAR. Guidelines for the diagnosis and management of difficult-to-control asthma. Arch Bronconeumol. 2005;41:513-23.

17. National Heart, Lung and Blood Institute. National Asthma Education and Prevention Program. Guidelines for the Diagnosis and Management of Asthma, Full Report. 2007.

18. Brito GS, Wang WS, Roque ALF, Castro FFM, Giavina-Bianchi P, Kalil J. Avaliação de Implantação do Prontuário Eletrônico do Ambulatório da Divisão de Imunologia Clínica e Alergia do ICHC FMUSP. Revista Brasileira de Alergia e Imunopatologia 2004;27: 163. (Apresentação no XXXI Congresso de Alergia e Imunopatologia;2004;Belém, Brasil).

19. Consenso Latino-Americano sobre a asma de difícil controle. Drugs of Today. 2006;42:1-27.

20. Latin-American Consensus on Difficult-to-Control Asthma, 2008. Drugs Today. (Barc). 2008;44 Suppl 3:1-43.

21. Miller MR, Hankinson J, Brusasco V, Burgos F, Casaburi R, Coates A, et al. ATS/ERS Task Force. Standardization of spirometry. European Respiratory Journal. 2005;26:319-38, doi: 10.1183/09031936.05.00034805.

22. Pellegrino R, Viegi G, Brusasco V, Crapo RO, Burgos F, Casaburi R, et al. Interpretative strategies for lung function tests. European Respiratory Journal. 2005;26:948-68, doi: 10.1183/09031936.05.00035205.

23. Senna G, Passalacqua G, Schiappoli M, Lombardi C, Wilcock L. Correlation among FEV1, nitric oxide and asthma control test in newly diagnosed asthma. Allergy. 2007;62:207-8, doi: 10.1111/j.1398-9995.2006. 01250.x.

24. Rackemann FM. A cinical study of one hundred and fifty cases of bronchial asthma. Arch Intern Med. 1918;XXII:517-52.

25. Leung DYM, Nelson HS, Szefler SJ, Busse WW. Analyzing asthma phenotypes. J Allergy Clin Immunol. 2004;113:1-2.

26. Miranda C, Busacker A, Baltazar S, Trudeau J, Wenzel S. Distinguishing severe asthma phenotypes: Role of age at onset and eosinophilic inflammation. J Allergy Clin Immunol. 2004;113:101-8, doi: 10.1016/j. jaci.2003.10.041.

27. Platts-Mills TA. Local production of $\operatorname{IgG}, \operatorname{IgA}$ and $\operatorname{IgE}$ antibodies in grass pollen hay fever. The Journal of Immunology. 1979;122:2218-25.

28. Mosbech H, Dirksen A, Madsen F, Stahl Skov P, Weeke B. House dust mite asthma. Correlation between allergen sensitivity in various organs. Allergy 1987;42:456-63, doi: 10.1111/j.1398-9995.1987.tb00363.x.

29. Wardaw AJ, Brightling C, Green R, Woltmann G, Pavord I. Eosinophils in asthma and others allergic diseases. Br Med Bull 2000;56:985-1003, doi: 10.1258/0007142001903490.

30. Jatakanon A, Uasuf C, Maziak W, Lim S, Chung KF, Barnes PJ. Neutrophilic inflammation in severe persistent asthma. Am J Respir Crit Care Med. 1999;160:1532-9.

31. Sur S, Crotty TB, Kephart GM, Hyma BA, Colby TV, Reed CE, et al. Sudden-onset fatal asthma. A distinct entity with few eosinophils and relatively more neutrophils in the airway submucosa? Am Rev Respir Dis. 1993;148:713-9.

32. Fahy JV, Kim KW, Liu J, Boushey HA. Prominent neutrophilic inflammation in sputum from subjects with asthma exacerbation. J Allergy Clin Immunol. 1995;95:843-52, doi: 10.1016/S0091-6749(95) 70128-1.

33. Lamblin CL, Gosset P, Tillie-Leblond I, Saulnier F, Marquette CH, Wallaert B, et al. Bronchial neutrophilia in patients with noninfectious status asthmaticus. Am J Respir Crit Care Med. 1998;157:394-402.
34. Romagnani S. Regulation of the development of type 2 T-helper cells in allergy. Current Opinion in Immunology. 1994;6:838-46, doi: 10.1016/ 0952-7915(94)90002-7.

35. Kourilsky P, Truffa-Bachi P. Cytokine fields and the polarization of the immune response. TRENDS in Immunology. 2001;22:502-9, doi: 10. 1016/S1471-4906(01)02012-9.

36. Giavina-Bianchi P, Kalil J, Rizzo LV. Development of an animal model for allergic conjunctivitis: influence of genetic factors and allergen concentration on immune response. Acta Ophthalmol. 2008;86:670-5, doi: 10.1111/j.1600-0420.2007.01134.x.

37. Busse WW, Calhoun WF, Sedgwick JD. Mechanism of airway inflammation in asthma. Am Rev Respir Dis. 1993;147:S20-4.

38. Santing RE, Olymulder CG, Zaagsma J, Meurs H. Relantionship among allergen-induce early and late phase airway obstructions, bronchial hyperreactivity and inflammation in conscious, unrestrained guinea pigs. J Allergy Clin Immunol. 1994;93:1021-30, doi: 10.1016/S00916749(94)70051-6.

39. Agondi RC, Barros MT, Rizzo LV, Kalil J, Giavina-Bianchi P. Allergic asthma in patients with common variable immunodeficiency. Allergy. 2010;65:510-5, doi: 10.1111/j.1398-9995.2009.02211.x

40. Giavina-Bianchi P, Fidalgo S, Duarte AJS. Hipersensibilidade dos pacientes com asma e rinite na cidade de São Paulo. Arch Argent Inmunol Clín. 1996;27:12. (Apresentação no Congresso Latino Americano de Alergia e Imunologia;1996;New Orleans, EUA).

41. Ayres JG, Miles JF, Barnes PJ. Brittle asthma. Thorax. 1998;53:315-21, doi: $10.1136 /$ thx.53.4.315.

42. TENOR Study Group. Borish L, Chips B, Deniz Y, Gujrathi S, Zheng B, Dolan CM. Total serum IgE levels in a large cohort of patients with severe or difficult-to-treat asthma. Ann Allergy Asthma Immunol. 2005;95:247-53, doi: 10.1016/S1081-1206(10)61221-5.

43. Damasceno MAS. Morbidade hospitalar por asma: fatores associados à necessidade de internação no Hospital das Clínicas da Faculdade de Medicina da Universidade de São Paulo, entre 1996 e 1998. [dissertação]. São Paulo: Faculdade de Medicina, Universidade de São Paulo; 2002.

44. Minshall EM, Leung DYM, Martin RJ, Song YL, Cameron L, Ernst P, et al. Eosinophil associated TGF $\beta 1$ mRNA expression and airways fibrosis in asthma. Am J Respir Cell Mol Biol. 1997;17:326-33.

45. Rosa-Rosa L, Zimmermann N, Bernstein JA, Rothenberg ME, Khurana Hershey GK. The R576 IL-4 receptor alpha allele correlates with asthma severity. J Allergy Clin Immunol. 1999;104:1008-14, doi: 10.1016/S00916749(99)70082-5.

46. Sandford AJ, Chagani T, Zhu S, Weir TD, Bai TR, Spinelli JJ, et al. Polymorphisms in the IL4, IL4RA and FCERIB genes and asthma severity. J Allergy Clin Immunol. 2000;106:135-40, doi: 10.1067/mai. 2000.107926

47. Jongepier H, Boezen HM, Dijkstra A, Howard TD, Vonk JM, Koppelman GH, et al. Polymorphisms of the ADAM33 gene are associated with accelerated lung function decline in asthma. Clin Exp Allergy. 2004;34:757-60, doi: 10.1111/j.1365-2222.2004.1938.x.

48. Hall IP. Pharmacogenetics of asthma. Chest. 2006;130:1873-8, doi: 10. $1378 /$ chest.130.6.1873.

49. Taylor DR. beta-Adrenergic receptor polymorphisms: relationship to the beta-agonist controversy and clinical implications. Expert Opin Pharmacother. 2007;8:3195-203, doi: 10.1517/14656566.8.18.3195.

50. Bleecker ER, Postma DS, Lawrance RM, Meyers DA, Ambrose HJ, Goldman M. Effect of ADRB2 polymorphisms on response to longacting beta2-agonist therapy: a pharmacogenetic analysis of two randomized studies. Lancet. 2007;370:2118-25, doi: 10.1016/S0140-6736 (07)61906-0.

51. Kim SH, Hur GY, Choi JH, Park HS. Pharmacogenetics of aspirinintolerant asthma. Pharmacogenomics. 2008;9:85-91, doi: 10.2217/ 14622416.9.1.85.

52. Morgan WJ, Crain EF, Gruchalla RS, O'Connor GT, Kattan M, Evans R $3^{\text {rd }}$, et al. Results of a home-based environmental intervention in urban children with asthma. N Engl J Med. 2004;351:1068-80, doi: 10.1056/ NEJMoa032097.

53. Thomson NC, Chaudhuri R, Livingston E. Asthma and cigarette smoking. Eur Respir J. 2004;24:822-33, doi: 10.1183/09031936.04. 00039004 .

54. Bush RK, Prochnau JJ. Alternaria-induced asthma. J Allergy Clin Immunol. 2004;113:227-34, doi: 10.1016/j.jaci.2003.11.023.

55. Hansen NN, Eggleston PA, Krishnan JA, Curtin-Brosnan J, Rand CS, Patino CM, et al. Asthma-related health status determinants of environment control practices for inner-city preschool children. Ann Allergy Asthma Immunol. 2006;97:409-17, doi: 10.1016/S1081-1206(10) 60809-5

56. Black PN. Antibiotics for the treatment of asthma. Curr Opin Pharmacol. 2007;7:266-71, doi: 10.1016/j.coph.2006.11.013.

57. Corrigan CJ. Asthma refractory to glucocorticoids: the role of newer immunosuppressants. Am J Respir Med. 2002;1:47-54.

58. Leal OM. Análise de fatores potencialmente agravantes da asma brônquica em pacientes tratados com corticosteróides sistêmicos 
[dissertação]. São Paulo: Faculdade de Medicina, Universidade de São Paulo;1998.

59. Singh M, Bara A, Gibson P. Humidity control for chronic asthma. Cochrane Database of Systemic Reviews. 2002;2:CD003563.

60. Gotzsche PC, Johansen HK, Schmidt LM, Burr ML. House dust mite control measures for asthma. Cochrane Database of Systemic Reviews. 2004;4:CD001187.

61. Naspitz CK, Diniz C, Cândida Rizzo M, Fernández-Caldas E, Sole D. Human scalps as a reservoi of domestic mites. Lancet. 1997;349:404, doi: 10.1016/S0140-6736(97)80026-8.

62. Thomson NC, Chaudhuri R, Livingston E. Asthma and cigarette smoking. Eur Respir J. 2004;24:822-33, doi: 10.1183/09031936.04. 00039004.

63. Warman K, Silver EJ, Wood PR. Asthma risk factor assessment: what are the needs of inner-city families? Ann Allergy Asthma Immunol. 2006;97:S11-5, doi: 10.1016/S1081-1206(10)60779-X

64. Rabinovitch N, Strand M, Gelfand EW. Particulate levels are associated with early asthma worsening in children with persistent disease. Am J Respir Crit Care Med. 2006;173:1098-105, doi: 10.1164/rccm. 200509-1393OC.

65. Giavina-Bianchi PF Jr, Castro FF, Machado ML, Duarte AJ. Occupational respiratory allergic disease induced by Passiflora alata and Rhamnus purshiana. Ann Allergy Asthma Immunol. 1997;79:44954, doi: 10.1016/S1081-1206(10)63042-6.

66. Bettiol J, Sele J, Henket M, Louis E, Malaise M, Bartsch P, et al. Cytokine production from sputum cells after allergenic challenge in IgEmediated asthma. Allergy. 2002;57:1145-50, doi: 10.1034/j.1398-9995. 2002.23586.x.

67. Wilson DR, Merret TG, Varga EM, Smurthwaite L, Gould HJ, Kemp M, et al. Increases in allergen-specific IgE in BAL after segmental allergen challenge in atopic asthmatics. American Journal of Respiratory Critical Care Medicine. 2002;165:22-6.

68. Melillo G, Bonini S, Cocco G, Davis RJ, De Monchy JGR, Frolund L, et al. EAACI provocation tests with allergens. Report prepared by the European Academy of Allergology and Clinical Immunology Subcommittee on provocation tests with allergens. Allergy. 1997;52: $1-35$.

69. van der Veen MJ, Lopuhaa CE, Aalberse RC, Jansen HM, van der Zee JS. Bronchial allergen challenge with isolated major allergens of Dermatophagoides pteronyssinus: the role of patient characteristics in the early asthmatic response. J Allergy Clin Immunology. 1998;102:2431, doi: 10.1016/S0091-6749(98)70051-X.

70. Giavina-Bianchi P, Diniz LC, Agondi RC, Porter MH, Kalil J. Urticaria after specific bronchial challenge. J Allergy Clin Immunol. 2008;122:2145, doi: 10.1016/j.jaci.2008.04.004.

71. Hargreave FE, Dolovich J, Boulet LP. Inhalation provocation tests. Semin Respir Med. 1983;4:224-8, doi: 10.1055/s-2007-1012487.

72. Sterk PJ, Fabbri LM, Quanjer PH, Cockcroft DW, O'Byrne PM, Anderson SD, et al. Airway responsiveness: Standardized challenge testing with pharmacological, physical, and sensitizing stimuli in adults. European Respiratory Journal 1993;6:53-83.

73. Guidelines for Methacholine and Exercise Challenge Testing - 1999. American Journal Respiratory Critical Care Medicine. 2000;161:309-29.

74. Cochrane GM, Horne R, Chavez P. Compliance in asthma. Eur Respir Rev. 1999;93:763-9.

75. Smith JR, Mildenhall S, Nobel M, Mugford M, Shepstone L, Harrison BD. Clinician-assessed poor compliance identifies adults with severe asthma who are at risk of adverse outcomes. J Asthma. 2005;42:437-45.

76. AIRE. Rabe KF, Vermeire PA, Soriano JB, Maier WC. Clinical management of asthma in 1999: the Asthma Insights and Reality in Europe (AIRE) study. Eur Respir J. 2000;16:802-7, doi: 10.1183/09031936.00. 16580200 .

77. Adams RJ, Fuhlbrigge A, Guilbert T, Lozano P, Martinez F. Inadequate use of asthma medication in the United States: results of the asthma in America national population survey. J Allergy Clin Immunol. 2002;110:58-64, doi: 10.1067/mai.2002.125489.

78. Lai CK, De Guia TS, Kim YY, Kuo SH, Mukhopadhyay A, Soriano JB, et al. Asthma control in the Asia-Pacific region: the Asthma Insights and Reality in Asia-Pacific Study. J Allergy Clin Immunol. 2003;111:263-8, doi: $10.1067 /$ mai.2003.1668.

79. Neffen H, Fritscher C, Schacht FC, Levy G, Chiarella P, Soriano JB, et al. Asthma Insights and Reality in Latin America (AIRLA) survey. Rev Panam Salud Publica. 2005;17:191-7, doi: 10.1590/S1020-49892005000300007.

80. de Magalhães Simões, dos Santos MA, da Silva Oliveira M, Fontes ES, Fernezlian S, Garippo AL, et al. Inflammatory cell mapping of the respiratory tract in fatal asthma. Clin Exp Allergy. 2005;35:602-11, doi: 10.1111/j.1365-2222.2005.02235.x.

81. Vieira JE, Cukier A, Stelmach R, Kasahara DI, Gannam S, Warth M. Comparison of knowledge on asthma: doctors completing internal medicine residency and doctors completing medical school. São Paulo Med J. 2001;119:101-4.

82. Stelmach R, Robles- Ribeiro PG, Ribeiro M, Oliveira JC, Scalabrini A, Cukier A. Incorrect application technique of metered dose inhalers by internal medicine residents: impact of exposure to a practical situation. J Asthma. 2007:44:765-8, doi: 10.1080/02770900701645694.

83. National Asthma Education and Prevention Program. Expert Panel Report 3 (EPR-3): Guidelines for the Diagnosis and Management of Asthma-Summary Report 2007. J Allergy Clin Immunol. 2007;120:S94S138, doi: 10.1016/j.jaci.2007.09.029.

84. Bateman ED, Boushey HA, Bousquet J, Busse WW, Clark TJ, Pauwels RA, et al. GOAL Investigators Group. Can guideline-defined asthma control be achieved? The Gaining Optimal Asthma Control study. Am J Respir Crit Care Med. 2004;170:836-44, doi: 10.1164/rccm.200401033OC.

85. Nelson HS, Weiss ST, Bleecker ER, Yancey SW, Dorinsky PM, SMART Study Group. The Salmeterol Multicenter Asthma Research Trial: a comparison of usual pharmacotherapy for asthma or usual pharmacotherapy plus salmeterol. Chest. 2006;129:15-26, doi: 10.1378/chest. 129.1 .15

86. Oppenheimer J, Nelson HS. Safety of long-acting beta-agonists in asthma: a review. Curr Opin Pulm Med. 2008;14:64-9, doi: 10.1097/ MCP.0b013e3282f1980b.

87. Suissa S, Ernst P, Benayoun S, Baltazan M, Cai B. Low-dose inhaled corticosteroids and the prevention of death from asthma. N Engl J Med. 2000;343:332-6, doi: 10.1056/NEJM200008033430504.

88. Hanania NA, Chapman KR, Kesten S. Adverse effects of inhaled corticosteroids. Am J Med. 1995;98:196-208, doi: 10.1016/S0002-9343 (99)80404-5.

89. Sievert W, Holmes P, King RW. Oesophageal candidosis in patients on high-dose inhaled steroids. Lancet. 1992;339:1551-2, doi: 10.1016/01406736(92)91326-4

90. Aun MV, Ribeiro MR, Costa Garcia CL, Agondi RC, Kalil J, GiavinaBianchi P. Esophageal candidiasis--an adverse effect of inhaled corticosteroids therapy. J Asthma. 2009;46:399-401, doi: 10.1080/ 02770900902777783

91. Kanda N, Yasuba H, Takahashi T, Mizuhara Y, Yamazaki S, Imada Y, et al. Prevalence of esophageal candidiasis among patients treated with inhaled fluticasone propionate. Am J Gastroenterol. 2003;98:2146-8, doi: 10.1111/j.1572-0241.2003.07626.x.

92. Kobayashi Y, Yasuba H, Kudou M, Hamada K, Kita H. Esophageal candidiasis as a side effect of inhaled fluticasone propionate dry powder: recovery by switching over to hydrofluoroalkane-134a beclomethasone dipropionate (HFA-BDP). Int J Clin Pharmacol Ther. 2006; $44: 193-7$

93. Shuto H, Nagata M, Terashi Y, Yamaguchi M, Takizawa T, Shuto C, Watanabe K, Tosaka K, Okano M, Noguchi H. Esophageal candidiasis as complication of inhaled steroid therapy. Arerugi. 2003;52: 1053-64

94. Bisaccioni C, Aun MV, Cajuela E, Kalil J, Agondi RC, Giavina-Bianchi P. Comorbidities in severe asthma: frequency of rhinitis, nasal polyposis, gastroesophageal reflux disease, vocal cord dysfunction and bronchiectasis. Clinics (Sao Paulo). 2009;64:769-73.

95. International Consensus Report on the diagnosis and management of rhinitis. International Rhinitis Management Working Group. Allergy. 1994;49 (19 Suppl):1-34.

96. ARIA. Allergic rhinitis and its impact on asthma. Bousquet and ARIA Workshop Group. J Allergy Clin Immunol. 2001;108:S147-333, doi: 10. 1067/mai.2001.118891.

97. Bousquet J, Khaltaev N, Cruz AA, Denburg J, Fokkens WJ, Togias A, et al. World Health Organization;GA(2)LEN;AllerGen. Allergic Rhinitis and its Impact on Asthma (ARIA) 2008 update (in collaboration with the World Health Organization, GA(2)LEN and AllerGen). Allergy. 2008;63 Suppl 86:8-160, doi: 10.1111/j.1398-9995.2007.01620.x.

98. Leynaert B, Neukirch C, Liard R, Bousquet J, Neukirch F. Quality of life in allergic rhinitis and asthma. A population-based study of young adults. Am J Respir Crit Care Med. 2000;162(4 Pt 1):1391-6.

99. O'Connell EJ. The burden of atopy and asthma in children. Allergy. 2004;59 Suppl 78:7-11, doi: 10.1111/j.1398-9995.2004.00563.x.

100. Crystal-Peters J, Crown WH, Goetzel RZ, Schutt DC. The cost of productivity losses associated with allergic rhinitis. Am J Manag Care. 2000;6:373-8.

101. Schoenwetter WF, Dupclay L Jr, Appajosyula S, Botteman MF, Pashos CL. Economic impact and quality-of-life burden of allergic rhinitis. Curr Med Res Opin. 2004;20:305-17, doi: 10.1185/030079903125003053.

102. Worldwide variation in prevalence of symptoms of asthma, allergic rhinoconjunctivitis, and atopic eczema: ISAAC. The International Study of Asthma and Allergies in Childhood (ISAAC) Steering Committee. Lancet. 1998;351:1225-32, doi: 10.1016/S0140-6736(97)07302-9.

103. Upton MN, McConnachie A, McSharry C, Hart CL, Smith GD, Gillis $\mathrm{CR}$, et al. Intergenerational 20 year trends in the prevalence of asthma and hay fever in adults: the Midspan family study surveys of parents and offspring. BMJ. 2000. 8;321:88-92, doi: 10.1136/bmj.321.7253.88.

104. Bousquet J, Annesi-Maesano I, Carat F, Leger D, Rugina M, Pribil C, et al. Characteristics of intermittent and persistent allergic rhinitis: DREAMS study group. Clin Exp Allergy. 2005;35:728-32, doi: 10.1111/j. 1365-2222.2005.02274.x. 
105. Togias A. Rhinitis and asthma: Evidence for respiratory system integration. J Allergy Clin Immunol. 2003;111:1171-83, doi: 10.1067/ mai.2003.1592

106. Antonicelli L, Micucci C, Voltolini S, Senna GE, Di Blasi P, Visonà G, et al. Relationship between ARIA classification and drug treatment in allergic rhinitis and asthma. Allergy 2007;62:1064-70, doi: 10.1111/j. 1398-9995.2007.01470.x

107. Leynaert B, Neukirch F, Demoly P, Bousquet J. Epidemiologic evidence for asthma and rhinitis comorbidity. J Allergy Clin Immunol. 2000;106(5 Suppl):S201-5, doi: 10.1067/mai.2000.110151.

108. Linneberg A, Henrik Nielsen N, Frølund L, Madsen F, Dirksen A, Jørgensen T. Copenhagen Allergy Study. The link between allergic rhinitis and allergic asthma: a prospective population-based study. The Copenhagen Allergy Study. Allergy. 2002;57:1048-52, doi: 10.1034/j. 1398-9995.2002.23664.x

109. Crystal-Peters J, Neslusan C, Crown WH, Torres A. Treating allergic rhinitis in patients with comorbid asthma: the risk of asthma-related hospitalizations and emergency department visits. J Allergy Clin Immunol. 2002;109:57-62, doi: 10.1067/mai.2002.120554.

110. Stelmach R, do Patrocínio T Nunes M, Ribeiro M, Cukier A. Effect of treating allergic rhinitis with corticosteroids in patient with mild-tomoderate persistent asthma. Chest. 2005;128:3140-7, doi: 10.1378/chest. 128.5.3140.

111. Agondi RC, Machado ML, Kalil J, Giavina-Bianchi P. Intranasal corticosteroid administration reduces nonspecific bronchial hyperresponsiveness and improves asthma symptoms. J Asthma. 2008;45:754-7, doi: 10.1080/02770900802249149.

112. Taramarcaz P, Gibson PG. Intranasal corticosteroids for asthma control in people with coexisting asthma and rhinitis. Cochrane Database Syst Rev. 2003;CD003570.

113. Gibson PG, Henry RL, Coughlan JL. Gastro-oesophageal reflux treatment for asthma in adults and children. Cochrane Database Syst Rev. 2003;:CD001496.

114. Nordenstedt H, Nilsson M, Johansson S, Wallander MA, Johnsen R, Hveem $\mathrm{K}$, et al. The relation between gastroesophageal reflux and respiratory symptoms in a population-based study: the NordTrondelag health survey. Chest. 2006;129:1051-6, doi: 10.1378/chest. 129.4.1051.

115. Leggett JJ, Johnston BT, Mills M, Gamble J, Heaney LG. Prevalence of gastroesophageal reflux in difficult asthma: relationship to asthma outcome. Chest. 2005;127:1227-31, doi: 10.1378/chest.127.4.1227.

116. Szczeklik A, Nizankowska E, Duplaga M. Natural history of aspirininduced asthma. AIANE Investigators. European Network on AspirinInduced Asthma. Eur Respir J. 2000;16:432-6, doi: 10.1034/j.1399-3003. 2000.016003432.x.

117. Awad OG, Fasano MB, Lee JH, Graham SM. Asthma outcomes after endoscopic sinus surgery in aspirin-tolerant versus aspirin-induced asthmatic patients. Am J Rhinol. 2008;22:197-203, doi: 10.2500/ajr.2008. 22.3148 .

118. Ceylan E, Gencer M, San I. Nasal polyposis and the severity of asthma. Respirology. 2007;12:272-6, doi: 10.1111/j.1440-1843.2006.00964.x.

119. Pfaar O, Klimek L. Aspirin desensitization in aspirin intolerance: update on current standards and recent improvements. Curr Opin Allergy Clin Immunol. 2006;6:161-6.

120. EAACI/GA2LEN guideline: aspirin provocation tests for diagnosis of aspirin hypersensitivity. Nizankowska-Mogilnicka E, Bochenek G, Mastalerz L, Swierczyńska M, Picado C, Scadding G, Kowalski ML, Setkowicz M, Ring J, Brockow K, Bachert C, Wöhrl S, Dahlén B, Szczeklik A. Allergy. 2007;62:1111-8, doi: 10.1111/j.1398-9995.2007. 01409.x.

121. Newman KB, Mason UG, Shmaling KB. Clinical features of vocal cord dysfunction. Am J Respir Crit Care Med. 1995;152:1382-6.

122. Giavina-Bianchi P, Pinto LHE, Sayed S, Cukier A, Kalil J. Development of a specific questionnaire for the suspicion of DPV. In: AAAAI Annual Meeting, 2007, San Diego. J Allergy Clin Immunol. 2007a119:S165.

123. Martin RJ, Blager FB, Gay ML, Wood RP. Paradoxical vocal cord motion in presumed asthmatics. Semin Respir Med. 1987;8:332-7, doi: 10.1055/ s-2007-1012672.

124. O'Connell MA, Sklarew PR, Goodman DL. Spectrum of presentation of paradoxic vocal cord motion in ambulatory patients. Ann Allergy. 1995;74:341-4.

125. Christopher KL, Wood RP, Eckert RC, Blager FB, Raney RA, Souhrada JF. Vocal cord dysfunction presenting as asthma. N Engl J Med. 1983;308:1566-70, doi: 10.1056/NEJM198306303082605.

126. Corren J, Newman KB. Vocal cord dysfunction mimicking bronchial asthma. Postgrad Med. 1992;92:153-6.

127. Serpa SF. Aspergilose broncopulmonar alérgica: prevalência e critérios diagnósticos em pacientes asmáticos sensíveis ao Aspergillus fumigatus [dissertação]. Rio de Janeiro: Faculdade de Medicina da UFRJ;1997.

128. Varkey B. Allergic bronchopulmonary aspergillosis: Clinical perspectives. Immunol Allergy Clin North Am. 1998;18:479-501, doi: 10.1016/ S0889-8561(05)70018-7.
129. Patterson R, Greenberger PA, Randin RC, Roberts M. Allergic bronchopulmonary aspergillosis: Staging as an Aid to Management. Ann Intern Med. 1982;96:286-91.

130. Rosenberg M, Patterson R, Mintzer R, Cooper JB, Roberts M, Harris KE. Clinical and Immunologic Criteria for the diagnosis of allergic bronchopulmonary aspergillosis. Ann Intern Med. 1977;86:405-14.

131. Greenberger PA. Allergic bronchopulmonary aspergillosis. Current Reviews of Allergy and Immunology. J Allergy Clin Immunol. 2002;5:685-92, doi: 10.1067/mai.2002.130179.

132. Moser M, Crameri R, Brust E, Suter M, Menz G. Clinical aspects of allergic disease: Diagnostic value of recombinant Aspergillus fumigatus allergen I/A for skin testing and serology. J Allergy Clin Immunol. 1993;93:1-11, doi: 10.1016/0091-6749(94)90227-5.

133. Crameri R. Recombinant Aspergillus fumigatus allergens: From the nucleotide sequences to clinical aplications. Int Arch Allergy Immunol. 1998;115:99-114, doi: 10.1159/000023889.

134. Almeida MB, Bussamra MH, Rodrigues JC. ABPA diagnosis in cystic fibrosis patients: the clinical utility of $\operatorname{IgE}$ specific to recombinant Aspergillus fumigatus allergens. J Pediatr (Rio J). 2006;82:215-20, doi: 10.2223/JPED.1479.

135. de Oliveira E, Giavina-Bianchi P, Fonseca LA, França AT, Kalil J. Allergic bronchopulmonary aspergillosis' diagnosis remains a challenge. Respir Med. 2007;101:2352-7, doi: 10.1016/j.rmed.2007.06.018.

136. Juçara Zulli Mohovic. Análogos de Asp f 1 (alfa-sarcina, a mitogilina e a restrictocina) no diagnóstico e estadiamento da aspergilose broncopulmonar alérgica [tese]. São Paulo: Faculdade de Medicina, Universidade de São Paulo;2008.

137. Aun MV, Castro-Coelho AP, Montenegro FG, Kalil J, Agondi MV Giavina-Bianchi P. Hypogammaglobulinemia: Adverse Effect of Systemic Corticosteroid in Severe Asthma Patients. Pôster at AAAAI $66^{\text {th }}$ Annual Meeting; February 26 - March 2, 2010;New Orleans, USA. J Allergy Clin Immunol. 2010;in press.

138. Rosen FS, Eibl M, Roifman C, Fisher A, Volanakis J, Aiuti F, et al. Primary Immunodeficiency Diseases. Clinical and Experimental Immunology. 1999;118:1-28

139. Papadopoulou A, Mermiri D, Taousani S, Triga M, Nicolaidou P, Priftis KN. Bronchial hyper-responsiveness in selective IgA deficiency. Pediatr Allergy Immunol. 2005;16:495-500, doi: 10.1111/j.1399-3038. 2005.00316.x.

140. Cunningham-Rundles C. Bodian C. Common Variable Immunodeficiency: Clinical and Immunological Features of 248 Patients. Clinical Immunology. 1999;92:34-48, doi: 10.1006/clim.1999.4725.

141. Kokron CM, Errante PR, Barros MT, Baracho GV, Camargo MM, Kalil J, et al. Clinical and laboratory aspects of common variable immunodeficiency. Anais da Academia Brasileira de Ciências. 2004;76:707-26, doi: 10.1590/S0001-37652004000400007.

142. Kainulainen L, Varpula M, Liippo K, Svedsrtröm E, Nikoskelainem J, Ruuskanen O. Pulmonary abnormalities in patients with primary hypogammaglobulinemia. J Allergy Clin Immunol. 1999;104:1031-6, doi: 10.1016/S0091-6749(99)70085-0.

143. Thickett KM, Kumararatne DS, Banerjee AK, Dudley R, Stableforth DE. Common variable immune deficiency: respiratory manifestations, pulmonary function and high-resolution CT scan findings. Q J Med. 2002:95:655-62.

144. Masi AT, Hunder GG, Lie JT, Michel BA, Bloch DA, Arend WP, et al. The American College of Rheumatology 1990 criteria for the classification of Churg-Strauss syndrome (allergic granulomatosis and angiitis). Arthritis Rheum. 1990;33:1094-100, doi: 10.1002/art.1780330806.

145. Jennette JC, Falk RJ, Andrassy K, Bacon PA, Churg J, Gross WL, et al. Nomenclature of systemic vasculitides: proposal of an international consensusconference. Arthritis Rheum. 1994;37:187-92, doi: 10.1002/art. 1780370206

146. Guillevin L, Pagnoux C, Mouthon L. Churg-Strauss syndrome. Semin Respir Crit Care Med. 2004;25:535-45, doi: 10.1055/s-2004-836145.

147. Guillevin L, Lhote F, Gayraud M, Cohen P, Jarrousse B, Lortholary O, et al. Prognostic factors in polyarteritis nodosa and Churg-Strauss syndrome. A prospective study in 342 patients. Medicine (Baltimore). 1996;75:17-28, doi: 10.1097/00005792-199601000-00003.

148. Keogh K, Specks U. Churg-Strauss Syndrome. Semin Respir Crit Care Med. 2006;27:148-57, doi: 10.1055/s-2006-939518.

149. Oh MJ, Lee JY, Kwon NH, Choi DC. Churg-Strauss syndrome: the clinical features and long-term follow-up of 17 patients. J Korean Med Sci. 2006;21:265-71, doi: 10.3346/jkms.2006.21.2.265.

150. Watts RA, Carruthers DM, Scott DG. Epidemiology of systemic vasculitis: changing incidence or definition? Semin Arthritis Rheum. 1995;25:28-4, doi: 10.1016/S0049-0172(95)80015-8.

151. Tsurikisawa N, Taniguchi M, Saito H, Himeno H, Ishibashi A, Suzuki S, et al. Treatment of Churg-Strauss syndrome with high-dose intravenous immunoglobulin. Ann Allergy Asthma Immunol. 2004;92:80-7, doi: 10. 1016/S1081-1206(10)61714-0.

152. Giavina-Bianchi P, Giavina-Bianchi M, Agondi R, Kalil J. Three months' administration of anti-IgE to a patient with Churg-Strauss syndrome. J Allergy Clin Immunol. 2007;119:1279, doi: 10.1016/j.jaci.2007.01.041. 
153. Giavina-Bianchi P, Giavina-Bianchi M, Agondi R, Kalil J. Administration of anti-IgE to a Churg-Strauss syndrome patient. Int Arch Allergy Immunol. 2007;144:155-8, doi: 10.1159/000103228.

154. Winchester DE, Jacob A, Murphy T. Omalizumab for asthma (correspondence). N Engl J Med. 2006;355:1281-2, doi: 10.1056/ NEJMc061914.

155. Bargagli E, Rottoli P. Omalizumab treatment associated with ChurgStrauss vasculitis. Int Arch Allergy Immunol. 2007;145:268, doi: 10. $1159 / 000109296$.

156. Puéchal X, Rivereau P, Vinchon F. Churg-Strauss syndrome associated with omalizumab. Eur J Intern Med. 2008;19:364-6, doi: 10.1016/j.ejim. 2007.09.001.

157. Giavina-Bianchi P, Agondi R, Kalil J. One year administration of antiIgE to a patient with Churg-Strauss syndrome. Int Arch Allergy Immunol. 2008;146:176, doi: 10.1159/000113524.

158. Giavina-Bianchi P, Giavina-Bianchi M, Agondi R, Kalil J. Omalizumab and Churg-Strauss syndrome. J Allergy Clin Immunol. 2008;122:217-8, doi: $10.1016 /$ j.jaci.2008.05.024

159. Giavina-Bianchi P, Giavina-Bianchi M, Agondi RC, Kalil J. Anti-IgE in Churg-Strauss syndrome. Thorax. 2009;64:272-3.

160. Giavina-Bianchi P, Kalil J. Omalizumab administration in ChurgStrauss syndrome. Eur J Intern Med. 2009;20:e139, doi: 10.1016/j.ejim. 2008.12.008.

161. Wechsler ME, Wong DA, Miller MK, Lawrence-Miyasaki L. Churgstrauss syndrome in patients treated with omalizumab. Chest. 2009;136:507-18, doi: 10.1378/chest.08-2990.

162. Strunk RC, Mascia AV, Lipkowitz MA, Wolf SI. Rehabilitation of a patient with asthma in the outpatient setting. J Allergy Clin Immunol. 1991;87:601-11, doi: 10.1016/0091-6749(91)90374-W.

163. Ram FSP, Wellington SR, Barnes NC. Inspiratory muscle training for asthma (Cochrane Review). In: The Chochrane Library, Issue 3, 2008. Oxford: Update Software.

164. Calabraro LTYG. O impacto de um programa de reeducação respiratória em idosos asmáticos [dissertação]. São Paulo: Faculdade de Medicina, Universidade de São Paulo;2008.

165. Carvalho NS, Ribeiro PR, Ribeiro M, Nunes Mdo P, Cukier A, Stelmach R. Comparing asthma and chronic obstructive pulmonary disease in terms of symptoms of anxiety and depression. J Bras Pneumol. 2007;33:1-6.

166. Chan MTS, Leung DYM, Szefler SJ, Spahn JD. Difficult-to-control asthma: clinical characteristics of steroid-insensitive asthma. J Allergy Clin Immunol 1998;101:594-601, doi: 10.1016/S0091-6749(98)70165-4.

167. Woolcock AJ. Steroid resistant asthma: what is the clinical definition? Eur Respir J. 1993;6:743-7.

168. Spahn JD, Leung DYM, Surs W, Harbeck RJ, Nimmagadda S, Szefler SJ. Reduced glucocorticoid binding affinity in asthma is related to ongoing allergic inflammation. Am J Respir Crit Care Med. 1995;151:1709-14.

169. Adcock IM, Lane SJ. Mechanisms of steroid action and resistance in inflammation. Corticosteroid-insensitive asthma: molecular mechanisms. Journal of Endocrinology. 2003;178:347-55, doi: 10.1677/joe.0. 1780347.

170. Wenzel SE, Schwartz LB, Langmack EL, Halliday JL, Trudeau JB, Gibbs RL, Chu HW. Evidence that severe asthma can be divided pathologically into two inflammatory subtypes with distinct physiologic and clinical characteristics. Am J Respir Crit Care Med. 1999;160:1001-8.

171. Gibson PG, Simpson J, Saltos N. Heterogeneity of airway inflammation in persistent asthma: Evidence of neutrophilic inflammation and increased sputum interleukin-8. Chest. 2001;19:1329-36, doi: 10.1378/ chest.119.5.1329.

172. Douwes J, Gibson P, Pekkanen J, Pearce N. Non-eosinophilic asthma: importance and possible mechanisms. Thorax. 2002;57:643-48, doi: 10. 1136/thorax.57.7.643.

173. Djukanovic R, Wilson SJ, Kraft M, Jarjour NN, Steel M, Chung KF, et al. Effects of treatment with anti-immunoglobulin E antibody omalizumab on airway inflammation in allergic asthma. Am J Resp Crit Care Med. 2004;170:583-93, doi: 10.1164/rccm.200312-1651OC.

174. Humbert M, Beasley R, Ayres J, Slavin R, Hebert J, Bousquet J, et al. Benefits of omalizumab as add-on therapy in patients with severe persistent asthma who are inadequately controlled despite best available therapy (GINA 2002 step 4 treatment): INNOVATE. Allergy. 2005;60:309-16, doi: 10.1111/j.1398-9995.2004.00772.x.

175. Fahy JV, Fleming HE, Wong HH. The effect of an anti-IgE monoclonal antibody on the early- and late-phase response to allergen inhalation in asthmatic subjects. Am J Respir Crit Care Med. 1997;155:1828-34. 